\title{
Towards a New Global Development Paradigm AND RESTRUCTURING THE ECONOMY INTO A SUSTAINABLE
}

\author{
Eva Pechočiaková Svitačová ${ }^{1}$, Danka Moravčíková ${ }^{2}$
}

\begin{abstract}
The current economy transcends the boundaries of sustainability, threatens the quality of life on Earth and, ultimately, of the man himself, which requires its restructuring to a sustainable one. The unsustainability of the development of society, which causes the development of the economy in a global environment, is revealed by theoretical research based on qualitative analysis of texts and documents. Subsequently, the need to change the paradigmatic basis of economic theory is explained and a new model of economy sustainable economy - is outlined. Using logical methods and comparison of basic axioms, postulates and based on the prediction of further development, the study emphasizes that moving towards a more sustainable future presupposes the replacement of neoclassical paradigm by a new paradigm - the paradigm of sustainable development. Restructuring the economy into a sustainable one will be based on this paradigm, as confirmed by some of the outlined new economic theories and initiatives.
\end{abstract}

\section{Keywords}

Economy, Restructuring, Sustainable Development, New Global Development Paradigm, Sustainable Economy

\section{Introduction}

Today's global civilization pays considerable attention to the developing economy, which is a promise of better quality of life. It cannot be denied that the economy developing in global environment is characterized by the development of economic relations in a global scale, by the growth of world trade, by increasing flows of direct investments, the growth of international production, and so on. It plays an important role in the development of global civilization but, at the same time, its development is accompanied by a number of problems, including the burden on natural resources and the ecosystem, by productive as well as

\footnotetext{
${ }^{1}$ Slovak University of Agriculture in Nitra, Tr. Andreja Hlinku 2, 94976 Nitra, Slovakia. E-mail: eva.svitacova@uniag.sk.

${ }^{2}$ Slovak University of Agriculture in Nitra, Tr. Andreja Hlinku 2, 94976 Nitra, Slovakia.

E-mail: danka.moravcikova@uniag.sk.
} 
unproductive human activity, whereby there are negative changes in the environment ecological, environmental, social, and other problems - that have global character. Due to this, it is currently not possible to assign the adjective "sustainable" to the economy in global environment. Ultimately, it cannot ensure quality conditions for the lives of current generation and generations after this. Consequently, it is not possible to assign as "sustainable" even the society in which this economy shall satisfy the needs of its members and ensure their quality of life.

The aim of the study is to point out that this situation has becoming the subject of criticism and debates in public, in professional circles, as well as in political structures, but it is also the topic of professional and scientific discourses and analyses. Their aim is to find solutions and new ways for the functioning of global economy without these negative accompanying phenomena and changes, i.e. solutions that, directly or indirectly, call for restructuring the economy and subsequently society into the sustainable ones. However, the fulfilment of these goals requires the change in paradigmatic basis of economic theory. It is related to the entry of the new global development paradigm - paradigm of sustainable development - which represents a hope for ensuring the long-term sustainability in all areas of wealth creation and distribution in society and nature.

\section{Economic Development in the Global Environment Versus Sustainability}

Development of economy in the global environment is associated, among other things, with the emergence of environmental, social and other problems, risks and crises, while people and mainly the economic entities are responsible for their deepening as well as for their mitigating and eliminating. Besides the empirical studies and research reports, also several theoretical studies and essays (see, for example, Meadows et al., 1972; Juvin and Lipovetsky, 2012; etc.) are sources of the knowledge that the processes of industrialization and economic development in the new global environment are related to negative externalities, so they bring undesirable side effects, eventually damages that have significant share in negative changes of environmental quality. In this way, they threaten the quality of life on Earth and, ultimately, of human himself (It is about the industrial model of the economy - conventional linear and economic model - that has shone in conditions of abundance of resources).

The neoclassical paradigm, which prefers methodological individualism, has an obvious influence in contemporary economic theory while, at the same time, it is abstracting from social, ecological and other influences that economic activities have on individuals, groups, society as a whole, respectively, on natural resources (Paulík and Valach, 2006). Overall, we can agree that from the historical point of view, the paradigms of economic theory were formed at a time when the issues of sustainable development were not so relevant due to the relative abundance of limited resources, and thus may not had been the subject of interest of economic theory. In the period of emergence of the classical and neoclassical economic theory, there were still no reasons to examine the exhaustibility of limited resources (Paulík and Valach, 2006). 
The issues of sustainable development started to be topical for economic theory only at the time, when, in the interest of further extensive development, the depletion of limited resources (especially natural ones) gradually became apparent, and the differences in living standards of individuals but also nations, and the differences between the global North and the global South became widened. And also, because of the negative consequences of people's economic activities on the environment. Although, human has been "adapting" the natural environment for its purposes through productive activities since long time ago, it humanized nature (The humanization of nature is a gradual transformation of natural environment. It is realized by practical interference in the original natural conditions and relationships, by transforming nature through human activity), while there have been changes in the environment. However, an increase of socio-cultural burden of the nature has gradually become a problem.

H. Jonas critically states that: the "humanization of nature" is a hypocritical verbal phrase for embellishing its complete subordination to human for the purpose of its full exploitation for his needs (Jonas, 1997). This is also confirmed by the so-called ecological footprint, which exceeds the biocapacity of the Earth per capita, but also by global production and consumption, which exceed the reproductive capacity of the Earth. As it is stated: ecological footprint calculations help us to evaluate the size of our dependence (WWF report, 2019).

The findings on ecological footprint are important as they point to how far humanity is from a safe and fair area of operation, and thus they represent a warning. Among other things, they promote the incorporation of the risk of global ecological overshoot into economic decision-making. The ecological footprint methodology is one that combines carbon emissions with all other competing human requirements on nature. It answers the central question: How much nature do we have and how much do we use? Based on present development, there are two options for the future. They encourage us to think seriously about whether we will continue to develop our business and economy at the current pace, respectively, in what ways we will strive for its development. About the achieving of the so-called carbon neutrality, the EU as well as some other world institutions or fora have been negotiating. As the Earth's capacity is limited, it is clear that with the development of industry and business the need to ensure carbon neutrality and reduce emissions has becoming more urgent (see Figure 1).

The ecological footprint, but also the reduced carrying capacity, as well as the ecosystem resilience, point out, among other things, that the industrial model of economy has hit these limits. It originated in different economic, social and civilizational conditions, and at the time when there were enough resources and space for unlimited growth, unlimited resource consumption and unlimited waste production, but it has gradually started to be associated with the unlimited expansion in all directions, and thus came into the conflict with the environment, resp. nature. As stated, today it does not respect the limitedness of resources of the Earth, the space for growth, as well as the "limitedness" of the space for waste storage, and it is characterized by unlimited expansion in all directions in time and space (Klinec, 2000). In addition, the anthropocentric paradigm, which is considered as a modern cultural model of Western civilization, but which represents an obstacle for 
a more sustainable future, has dominant influence at present. According to this, the value of any object, including the value of living organisms, is understood as a value for human, and so the whole nature is understood exclusively as a source for human use and utilization.

Figure 1: How many Earths does it take to support humanity?

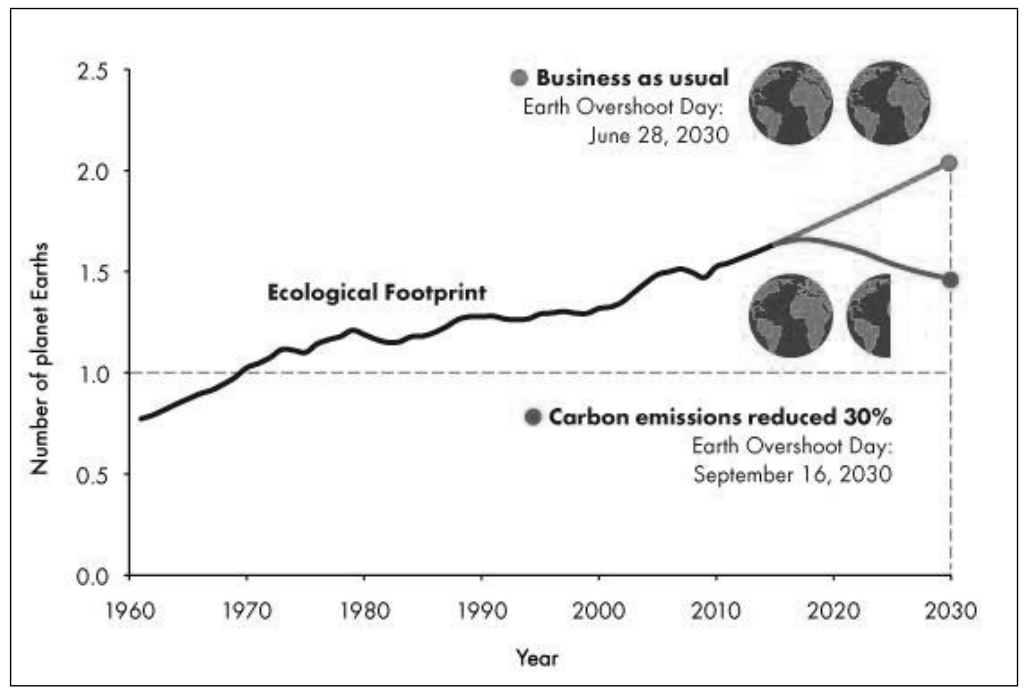

Source: Wahl et al., 2017

A. Naess states that drastic interventions in nature reflect our economic activities (Naess, 1996). He openly criticizes these drastic interventions of humans in nature to increase human well-being, while stating: "Protecting of what is remaining of the untouched nature will depend to a large extent on our willingness and ability to change today's production and consumption way - as well as on our ability to abandon the ideologies that justify today's economic rape of our planet" (Naess, 1996, p. 188). This warning refers to all spheres of society and all people. However, many people are missing environmental awareness, that "plays a crucial role in managing pro-environmental decisions and individual behaviour and human participation, as well as activity is essential to solve environmental problems" (Mravcová, 2019, p. 46). Mainly people in developed countries have significant share on the emergence of global environmental crisis, assigned as the crisis of global industrial civilization. The origin of this crisis and the overall state of the environment are also associated with the development of neoclassical economy, which currently has considerable problems in explaining economic phenomena and processes associated with integration and globalization. We incline to the idea that neoclassical economics cannot offer effective ways to reduce the instability of current economic systems, and so we are experiencing a crisis of neoclassical paradigm in economics (Sojka, 2009). Neoclassical paradigm represents a theoretical system based on rationality, methodological individualism, and utilitarianism. 
From its point of view, the economy should focus primarily on the effective achievement of economic goals, respectively, creation of product and surplus product. At the same time, historical, social, psychological, and other aspects are being ignored. The role of other values appears only at non-economic "exchanges". At the same time, it is clear that only commodity values cannot be considered as values, because values that have noneconomic character are also related to economic activity. However, the market takes only little into account the non-economic goals and values, which has harmful consequences for the environment. Only what is considered as a rareness or a scarce commodity has the value. What is "for free", such as natural resources, is not considered as the value. It is not included in costs and, on this basis, natural resources are treated inconsiderately. However, we incline to the opinion that it is important to understand the ethical problems related to economic values, or to be aware of the "tension" between economic interests and environmental protection (Lomnický, 2019).

The economic man (The neoclassical paradigm is based on the model of economic man homo oeconomicus - however, clearly prefers economic interests and maximizes his benefit in conditions of "scarcity", while this scarcity relates mainly to non-renewable natural resources (see more in Sojka, 2009). He thus transcends natural systems, through what he negatively affects the environment, which causes changes that existentially endanger the lives of people on Earth. This is confirmed not only by the ecological footprint but also by the reduced carrying capacity and ecosystem resilience, i.e. the ability of ecosystem to maintain the key functions and processes, and to face stress or pressures (see, for example, WWF report, 2019). At the same time, in our point of view, maintaining the stability of ecosystems is necessary to achieve sustainable economic development. The condition for the continued existence of human on Earth is becoming a holistic view of the economy and, from this point of view, its interpretation. We are missing the economy based on the understanding of broader relationships and contexts.

\section{Bases of the New Economic Paradigm and the Development of Sustainable Economy}

At the end of the 20th century the need to restructure economy, to take into account the ecology, has begun to be considered. This reconstruction assumes the harmonization of paradigmatic starting points of ecology and economy. As stated, "The 21st century is opposed to the 20th century, as the 'century of ecology' versus the 'century of economy'. In political economy, the new school of economic thinking began to shape, recognizing the axiom according to which the whole economic activity is significantly influenced by ecological, social, and ethical realities and reflections" (Černík, 2011, p. 788). This can be considered as a response to reducing the productive capacity of nature, disrupting the interrelationships between various components of nature and, in general, to ineligible changes in the environment that have a negative impact on human himself. As stated, humanity must make the transition to a sustainable economy that takes into account own biosystem's limits of biophysical ecosystem, so that it can exist for a long time. The view arises, that if we do not make this transition, we could be affected not only by uneconomic growth but also by ecological catastrophe (see more in Daly, 2007). 
The activities of the Club of Rome have undoubtedly made significant contribution to searching for the future model of economy - sustainable economy. The Club's main philosophy is considered to be the sustainable development of society and civilization. This is also confirmed by the New Report of the Club of Rome made by E. Ulrich won Weizsäcker and the Lovins spouses, where the authors convincingly argue that there are the means to ensure that the market maintains a healthy environment, while making possible to reach profit for every participant. At the same time, however, they state that the market is largely deformed. It is developing against the interests of the environment, and therefore it is necessary to correct it. The solution would also be the emergence of "eco-capitalism", which is based on the environmentally friendly market, as outlined by the World Summit in Rio (for more details, see Weizsäcker, Lovins and Lovins, 1998). It should be developed in sustainable way, based on sustainable management, efficient use of natural resources, minimization of negative impacts on human health, environment, and nature.

One of the critics of contemporary economics is the American physicist and theorist of new paradigm F. Capra. According to him, economy is characterized by the fragmentary and reductionist approach, while it is calling for change in the paradigmatic basis of economic theory founded on the holistic perception and vision to the holistic interpretation of current economic problems (see more in Capra, 1982). It is based on the systemic approach to life (According to Capra, one of the most important findings of the systemic view on life is the knowledge that networks are the basic model of organization of all living systems [for more details see, for example, Capra, 1997]) and it emphasizes that we live in the interconnected, global world, where all phenomena (biological, psychological, etc.) are related to each other. He understands the world as an organism of interconnected and interdependent physical, biological, psychological, social, cultural phenomena, while stressing the importance of maintaining social and ecological balance in it. Otherwise it will begin to fall into the crisis. The economy must also be understood in terms of systemic perspective as the living system in which the components are interconnected by complex network of interdependencies (for more details see, for example, Capra, 1997).

Systemic thinking is also emphasized by American futurologist H. Henderson. As one of the fundamental defaults of current economy she marks the marginalization of the fact that human activities are carried out within society and society is part of the ecosystem. According to her, the problem is subsidizing the economy with nature. According to Henderson (2001), fundamental change in the perception of economic reality is represented by the understanding of economy as a subsystem or part of higher systems (society, nature, or the universe). According to her, the transition to sustainable economy requires systemic approach, multidisciplinary approach, and involvement of many departments and measurement systems.

The need for the change in economic theory in connection with the change in economic reality is also reflected by E. F. Schumacher, who clarifies the need of the so-called metaeconomy, based on the understanding of broader relationships and connections within society and community. Given the accumulating evidence of environmental degradation, especially in the animated nature, Schumacher claims that it is possible to question the whole perspective and methodology of the economy. The study of economy is too narrow 
and too fragmented to lead to valid knowledge unless it is supplemented by the study of meta-economics. In this context, Schumacher clarifies: "As economics deals with man in his environment, we may expect that meta-economics consists of two parts - one dealing with man and the other dealing with the environment. In other words, We may expect that economics must derive its aims and objectives from a study of man, and that it must derive at least a large part of its methodology from a study of nature" (Schumacher, 1973, pp. 33-34).

The World Economic Forum also points out that the economy is damaging people and planet, and thus constituting "the tragedy of the commons". The economy is still incapable to internalize the real costs of our planet. At the same time, the greatest economic threat to humanity today is considered to be its inability to respect the nature (World Economic Forum, 2017).

Several theorists (economists, lawyers, political scientists, sociologists, technicians, and politicians) are now starting to think in a broader context, recognizing the dependence of economy on the environment, and the resources it uses and influences backward. They are addressed with the concept of sustainable development (The most well-known definition of sustainable development is presented in the Brundtland Report [World Commission on Environment and Development, 1987]). In the broadest sense, it seeks to establish harmony between human beings, and between humanity and nature to promote inclusive and sustainable economic growth as well as well-being for all.

There is no doubt that sustainable development can positively influence the transformation of economic theory and its change on the basis of the holistic worldview so that the economy is examined in a broader contexts and concepts, as some theorists pointed out. In accordance with the concept of sustainable development, subjects in the economy should strive to achieve sustainable economic growth (Besides the sustainable growth, sustainable degrowth has currently being considered in the economy. It is considered by N. Georgescu-Roegen, who considers himself the founder of ecological economics, while J. van den Bergh tried to make a more detailed definition of this so-called concept of sustainable degrowth [see more in, van den Bergh, 2011]) as well as sustainable economic development. Thus, the purpose of this concept is not only to protect the environment. It is required to achieve the growth that is fair and provides the opportunity for all people of the world, not just for the privileged ones, without further destruction of the world's non-renewable natural resources and regarding the planet's carrying capacity (UNDP, 1992). The concept of sustainable development is considered to be the global development paradigm, but also the basic development paradigm of the 21st century (for more details, see Blažej, 2005). And also, the project to reconcile economic and social development with the requirement of environmental protection, while the economic system must be based on the alternative value orientations that support the direction towards sustainable development (see more, for example, in Klinec, 2000). The aim of such project is to seek harmony between human and nature, between society and its environment, so that we get as close as possible to the ideals of humanism, and respect for life and nature in all its forms. 
The value reorientation of human, society, and civilization is one of the basic characteristics of the concept of sustainable development, which creates frameworks also for economic theories supporting sustainable development. Sustainable development presupposes the reassessment of recognized values, understanding and acceptance of new values. It is not only about humanity, but also about environmental values (Smolková, 2003), especially about nature and natural entities, which are considered to be universal values, and so they should also enter into the value judgments, thereby eliminating the neutral assessment of nature, natural phenomena and processes. Based on the conscious awareness of the value of nature, not only for its usefulness, but especially for its uniqueness, some entities are currently able to propose new economic theories and develop new initiatives on behalf of sustainable economic development. In this way, they advocate the transformation of economy into the sustainable one.

Sustainable economy differs from the conventional industrial model by several features. For example, while the industrial model is based on the maximum consumption of goods and services, and the artificial promotion of such consumption, the sustainable model is based on diversifying human needs, natural consumption, minimizing waste production, consumption and energy, and on attributing the real value to the nature.

\section{Research Methodology}

Based on the fact that the development of global economy brings many undesirable side effects that threaten the quality of life on Earth and, ultimately, human himself, one of the aims of this study is to point out and justify that the economy can no longer focus on providing welfare to today's people at the expense of natural resources and negative changes in the environment that threaten the lives of current generation and future generations.

The changes and unsustainability of the development of society, caused by the development of economy in global environment, are revealed by qualitative research, which focuses on reality in all its complexity, in order to point out the need to change the paradigmatic basis of economic theory and sustainable development of economy. At the same time, we use it to justify that the new global paradigm - sustainable development - has become a new vision of reality and, at the same time, the basis in this century, on which the economy should also be constructed. Subsequently, we explicate the need to restructure the economy into the sustainable while, at the same time, the emergence of some new trends in economic thinking and new models or initiatives in the economy are highlighted in the sign of sustainability. Their aim is to link economic and social development with the requirement of nature as well as environmental protection, and thus to strive for the development of the economy in a sustainable manner.

The study is based on theoretical research, qualitative analysis of texts and documents, on the basis of which theoretical knowledge is accumulated. Subsequently, the basic axioms, postulates, and consequences are detected and interpreted as well as the further development is predicted. Theoretical sources are created from the information sources from several social sciences (monographs, journal literature, and electronic sources). Based on these sources, the study first looks critically at the state of nature and the overall state of environment, and then explicates that moving towards more sustainable future assumes 
the shift from neoclassical paradigm and its replacement by the holistic paradigm - new global development paradigm - paradigm of sustainable development. On this paradigm the development of sustainable economy and society in global environment shall be based, while an important precondition for the development of sustainable society is the restructuring of economy into the sustainable one. Clarifying the need for paradigm change requires pointing out the different social conditions in which both paradigms originated, revealing the different values and postulates on which they are based, while, besides the comparison, also the logical methods and methods leading to the spread of knowledge are used. Subsequently, some new trends in economic thinking and new initiatives in the economy are outlined, which confirm the fact that many entities have been already making efforts to build and develop sustainable economy.

\section{Results and Discussion}

We consider as significant progress, that some new theories and initiatives in the economy are already being really marked by the abovementioned characteristics and features. Economy is there understood as an inseparable part of society, determined by the functioning of non-economic structures of social life. They focus not only on the study of economic structures and relationships, but also on the background of the natural and social environment.

In addition to Environmental Economics, through which neoclassical economic theory has responded to environmental issues since the early 1970s, a new economic theory is, for example, Ecological Economics, which central concept is sustainable development. Environmental economics deals mainly with pollution and monetization, respectively, with optimizing environmental externalities and the impact of the economy on the environment. Its aim is to identify specific instruments that should regulate the market so that there is the most efficient use and distribution of natural resources, which are finite. In this way, it strives to achieve the maximum possible benefit in the most efficient ways (see more in, for example, Kolstad, 2000). The main difference between the neoclassical economy and new economic theories based on the global development paradigm is that the neoclassical economy focuses mainly on production and consumption, and does not address the role of ecological system in the economy at all, while ecological economy understands human society as a subset of the permanent global ecosystem (for more details, see Kibert et al., 2018).

Sustainable economic development is considered to be the greatest economic opportunity of the 21 st century, which should lead to significant changes in local, regional, and national economic development strategies and practices. Whether this will be so or not depends not only on economic subjects and economic institutions themselves, but also on political decisions that should reflect the problems in global environment and the concerns of its residents about their future and the future of their children. We consider as a step forward that, in order to promote sustainable economy, the EU Circular Economy Action Plan was adopted in Europe - one of the main building blocks of the European Green Deal, Europe's new agenda for sustainable growth. New Action Plan aims to make our economy fit for a green future, strengthen our competitiveness while protecting the environment and 
give new rights to consumers. Building on the work done since 2015, new Plan focuses on the design and production for the circular economy, with the aim to ensure that the resources used are kept in the EU economy for as long as possible (see more in European Commission, 2020).

\section{Conclusion}

As in other areas of society life, the global development strategy has also been gradually implemented in the economy, and under its influence the paradigmatic basis of economic theory has been changing and the economy has been reconstructed. The main stimuli for this change include social pressures that arose as the result of deteriorating state of the environment as well as theoretical analyses of some experts and their warning predictions, which certainly cannot be ignored. Many experts indirectly agree that, from the point of view of the neoclassical paradigm, economic activities coordinate the market forces, and neoclassical economic theory only explains the efficient use of limited resources in terms of present. At the same time, it does not pay attention to the global environmental problems and to the issue of sustainable development. This suggests the need to move away from this paradigm, to understand broader the relationships and contexts within society, community, or the need for the so-called meta-economy, which can, among other things, help reduce the socio-cultural burden on nature, prevent the deepening of existing global problems, risks, and crises in the world, and increase the quality of life in the new global environment.

The abovementioned findings and opinions, and also many others, on which we rely, confirm in some way the need to reconcile economic and social development with the requirement of environmental protection, which requires replacing the neoclassical paradigm with the holistic paradigm - new global development paradigm. It is the new holistic paradigm of science and scientific thinking, which is based on the understanding of life, organism, and the world as a whole, in which individual phenomena are interconnected and interdependent. It brings the holistic view on economy, characterized by understanding the world economy and world civilization as one whole and it represents the hope for ensuring long-term sustainability in all areas of wealth creation and distribution in society and nature. It is also considered to be the basic development paradigm of the 21 st century, and also the project that connects economic and social development with the requirement of environmental protection. According to this, economic subjects should behave in such a way that they do not restrict the possibilities of the use of limited resources by future generations. This requires the value reorientation of human, society, and civilization, which is one of the basic characteristics of the concept of sustainable development. In this respect, it is necessary, in particular, to deflect from the anthropocentric principle and do not consider the nature exclusively as resource for human use and exploitation. Value reorientation is also the basis of new idea of the so-called "homo oeconomicus", who recognizes the responsibility towards other people and nature as a whole, including responsibility towards future generations.

Restructuring the economy into the sustainable one has been shaping as one of the solutions to prevent deepening of existing global problems and crises in the world, and to offer new 
opportunities for the promotion of economic interests on the global scale, without endangering current generation and future generations. At the same time, sustainable economy is establishing new lifestyle that respects the carrying capacity of nature and the whole ecosystem, and that creates new culture of consumption.

More specifically, it was outlined that restructuring of current economy into the sustainable one is practically realized through the development of new economic theories and initiatives, which confirm that the concept of sustainability is gradually finding space in current economy and it is encouraging changes to this system. The common feature of new economic theories and initiatives is the effort to ensure economic, social, and ecological well-being on the basis of efficient use of resources and minimal burden on the environment.

Sustainable economic development is considered to be the greatest economic opportunity of the 21 st century, which will lead to significant changes in economic development of individual parts of the world.

\section{References}

Blažej, A. (2005). Udržatelný rozvoj - základná rozvojová paradigma 21. storočia. Bratislava: Dialógy v EU.

Capra, F. (1982). The Turning Point: Science, Society, and the Rising Culture. New York: Simon and Schuster.

Capra, F. (1997). The Web of Life: A New Scientific Understanding of Living Systems. New York: Anchor Books.

Černík, V. (2011). Spory o otázke „prirodzenosti““ a „slobody“ súčasného kapitalizmu. Filozofia, 66(8), 782-793.

Daly, H. (2007). Ecological Economics and Sustainable Development. Selected Essays of Herman Daly. Cheltenham: Edward Elgar Publishing.

European Commission. (2020). EU Circular Economy Action Plan. Retrieved March 21, 2020, from https://ec.europa.eu/environment/circular-economy/index_en.htm.

Henderson, H. (2001). Za horizontem globalizace. Utváření udržitelné globální ekonomiky. Praha: Dharma Gaia.

Jonas, H. (1997). Princip odpovědnosti. Praha: OIKOYMENH.

Juvin, H. and Lipovetsky, G. (2012). Globalizovaný Západ. Polemika o planetární kultuře. Praha: PROSTOR.

Kibert, Ch. J. et al. (2018). The Ethics of Sustainability. Retrieved February 20, 2020, from https://epale.ec.europa.eu/en/resource-centre/content/ethics-sustainability.

Klinec, I. (2000). Alternatívne ekonomické teórie podporujúce smerovanie k trvalo udržatelnému rozvoju. Bratislava: Prognostický ústav SAV. Retrieved March 22, 2020, from https://www.researchgate.net/publication/266505934_Alternativne_ekonomicke_teorie_ podporujuce_smerovanie_k_trvalo_udrzatenemu_rozvoju?enrichId=rgreq-96a347ba95c092803c7e7d9afeeca1e4-XXX\&enrichSource=Y292ZXJQYWd1OzI2NjUwNTkzNDtBUzoyMjU2OTM1MjM4MTIzNTJAMTQzMDgyMDkzNzMxNQ\%3D\%3D\&el=1_x_2\& _esc=publicationCoverPdf. 
Kolstad, Ch. D. (2000). Environmental Economics. New York: Oxford University Press. Lomnický, I. (2019). Rozvíjanie tvorivého a kritického myslenia v etickej výchove. Duchovičová, J., Hošová, D., Koleňáková, R. Š. (eds). Inovatívne trendy v odborových didaktikách. Prepojenie teórie a praxe výučbových stratégii kritického a tvorivého myslenia. Nitra: PF UKF, 356-363.

Meadows, D. L. et al. (1972). The limits to growth. A Report for the club of Rome's Project on the Predicament of Mankind. New York: Universe Books.

Mravcová, A. (2019). Environmental awareness and environmental citizenship dimension. Slovak Journal of Political Sciences, 19(2), 32-48, https://doi.org/10.34135/sjps.190202. Naess, A. (1996). Ekologie, pospolitost a životní styl. Praha: ABIES.

Paulík, T. and Valach, E. (2006). Trvalo udržatel'ný rozvoj pohladom ekonomickej teórie. Národný obzor, 1, 61-72. Retrieved May 01, 2020, from https://is.muni.cz/do/1456/soubory/aktivity/obzor/6182612/7667845/08PaulikValach.pdf.

Schumacher, E. F. (1973). Small is Beautiful. Economics as If People Mattered. London: Blond \& Briggs. Retrieved March 19, 2020, from http://www.daastol.com/books/Schumacher\%20(1973)\%20Small\%20is\%20Beautiful.pdf.

Smolková, E. (2003). Environmentálne hodnoty v hodnotových systémoch. Filozofia, 58(7), 471-483.

Sojka, M. (2009). Stane se institucionální ekonomie paradigmatem 21. století? Politická ekonomie, 57(3), 297-304, https://doi.org/10.18267/j.polek.685.

UNDP. (1992). Human Development Report. New York: Oxford University Press. Retrieved April 28, 2020, from http://hdr.undp.org/sites/default/files/reports/221/hdr_1992_en_complete_nostats.pdf.

Van den Bergh, J. C. J. M. (2011). Environment versus growth: a criticism of "degrowth" and a plea for "a-growth". Ecological Economics, 70(5), 881-890, https://doi.org/10.1016/ j.ecolecon.2010.09.035.

Wahl, D. C. (2017). Ecological Footprint, Earth Overshoot Day and the Happy Planet Index. Retrieved April 25, 2020, from https://medium.com/age-of-awareness/ecologicalfootprint-earth-overshoot-day-and-the-happy-planet-index-8ff5fc19af06/.

Weizsäcker, E. U., Lovins, A. B. and Lovins, L. H. (1998). Factor four. Doubling wealth, halving resource use. New report of the Rome Club. London: Routledge.

World Commission on Environment and Development. (1987). Our Common Future. Oxford: Oxford University press.

World Economic Forum. (2017). 5 reasons why the economy is failing the environment, and humanity. Retrieved May 25, 2020, from https://www.weforum.org/agenda/2017/01/5reasons-why-the-economy-is-failing-the-environment-and-humanity.

WWF Report. (2019). EU Overshoot Day. Living Beyond Nature's Limits. Brussels: Global Footprint Network. Retrieved May 26, 2020, from https://d2ouvy59p0dg6k.cloudfront.net/downloads/wwf_eu_overshoot_day_living_beyond_nature_s_limits_web.pdf. 